Int. J. Electrochem. Sci., 14 (2019) $11731-11743$

International Journal of

ELECTROCHEMICAL

SCIENCE

Www.electrochemsci.org

\title{
Preparation and Corrosion Resistance of Micro-arc Oxidation/Self-Assembly Composite Film on 6061 Aluminum Alloy
}

\author{
Ming Ming Ma, Yu Qing Wen*, Wei Shang*, Jia Ping Li \\ Guilin University of Technology, No. 12, Jiangan Road, Guilin City, Guangxi, China. \\ *E-mail: 2006027@glut.edu.cn
}

doi: $10.20964 / 2019.11 .52$

Received: 22 May 2019 / Accepted: 25 July 2019 / Published: 29 October 2019

\begin{abstract}
The aluminum alloy has some advantages and has wide application in modern life. However, aluminum alloys are easily corroded by corrosive substances in the environment, thus affecting their service life. In order to improve the corrosion resistance of the aluminum alloy surface, The composite film was prepared by micro-arc oxidation, self-assembly and doping, which were micro-arc oxidation (MAO), bis[3-(triethoxysilyl)propyl]tetrasulfide(BTESPT) and graphene oxide (GO). The morphology and composition of the composite film (MAO/BTESPT/GO) were tested by SEM, EDS. The salt spray test, Tafel polarization curve and electrochemical AC impedance were used to test the corrosion resistance of the composite film. The results shown that the micro-arc oxidation-self-assembled composite film had excellent corrosion resistance. And the corrosion current density of the composite film was reduced by 5 orders of magnitude compared with the substrate. The salt spray test results shown that the corrosion resistance of the composite film was greatly improved compared with that of the matrix and the selfassembled film. The composite film exhibited excellent corrosion resistance.
\end{abstract}

Keywords: Aluminum alloy; Micro-arc oxidation; Self-assembly; Graphene oxide

\section{FULL TEXT}

(C) 2019 The Authors. Published by ESG (www.electrochemsci.org). This article is an open access article distributed under the terms and conditions of the Creative Commons Attribution license (http://creativecommons.org/licenses/by/4.0/). 